\title{
Investigate on the Determinants of Economic Growth in Ethiopia
}

\author{
Habtu Nibret \\ Lecturer, departments of economics, Dembi dollo, Ethiopia
}

\begin{abstract}
The study examines the macroeconomics determinants of economic growth in Ethiopia measured by real gross domestic product (RGDP). We used time series data for a period of 27 years that is 1991 to 2017. Augmented Dickey-Fuller (ADF) test was used for the unit root test and the Autoregressive Distributed Lag under Bound test was also conducted to establish short and long run relationships between economic growth and its macroeconomics determinants. The result shows that there is co-integration, which establishes the existence of long run relationship among the variables. The results show that gross fixed capital formation, total labor force, total government expenditure and foreign direct investment are the main determinants of Ethiopia economic output in the long run where us total labor force and foreign direct investment are the main determinants of economic growth in Ethiopia in the short run. The study recommended that there is need for government to consciously develop the business environment by provision of necessary infrastructure, which will lower the cost of doing business in Ethiopia. There is also the need for the government to retain tight monetary and fiscal policies in order to fight inflation in the Ethiopian economy, since inflation have negative influence on investment and Ethiopia economic growth and finally, There is needs to put stringent policy in place to minimized strike in Ethiopia labor sector in order to enhance their performance to the nation economy.
\end{abstract}

Keywords: Macroeconomics; Unit Root; Cointegration; Ethiopia; Real Gross Domestic Product.

DOI: $10.7176 / \mathrm{JESD} / 10-1-04$

\section{INTRODUCTION}

Human beings have always sought ways to improve their lives and living standards. To this end, growth and development has become the primary goal of every nation. The aspiration for economic growth and development is the result of experiences seen in the form of sustained elevation in an entire society towards a better life.

The basic function of all economic activities is to provide as many people as possible with means enough to meet basic needs and a level of material prosperity that guarantees worthiness and esteem. Moreover, economic growth increases the range of human choice i.e. Freedom. The average level of satisfaction increases with a country's level of income, of course, this is true up to a certain level (Todarro et al, 2009). Economic growth reduces scarcity and gives us more satisfaction (more goods and services). Thus, all societies try to achieve economic growth and development.

Economic growth theories and models highlight the different ways in which the present economic activity can have an influence on future economic developments and can also identify sources that may lead to continued economic growth. Researchers and economists reaffirm the need for economic growth for the evolution and well been of the human race. The economic growth theories have evolved over time depending on the period and on the dynamics of economy. Also improvements in mathematical and statistical tools have had a significant impact in formulating new concepts.

Why do we need economic growth? What are the main factors that foster growth? Many researchers, economists and Nobel Prize winners tried to answer these questions. Economic growth can be considered a main factor in the well being and prosperity of billions of people. Industrialization and advances in technology has left a gap between developed countries and poorer ones. For example now, in the 21 st century the GDP/capita of many poorer countries is lower than the GDP per capita of Europe in the 19th century. Economic growth was a pinnacle of the $20^{\text {th }}$ century that insured the development of the Western World and improved for many people leaving standards.

A number of parameters are employed to measure the economic progress of nations and evaluate the improvements in the living standards of citizens. One such measurement is real gross domestic product (GDP) or GDP per capita. Although there are difficulties in using real GDP per capita as a measure of the quality of life, it is reasonably correlated with other measures of well-being such as health and literacy. Economic growth improves living standards through many channels. It creates more jobs, accelerates investment, boosts business confidence, and increases the revenue to the state in the form of taxes.

Ethiopia is an agrarian economy which is still struggling with the problem of poverty. According to (The World Bank, 2016), greater than 80 percent of the total population lives in rural areas out of which more than 30 percent is poor. According to other UN sources, despite the stagnation in agricultural productivity, there are some success stories in Least Developed Countries.

In Ethiopia, for instance, there was a tripling of cereal production between 2000 and 2014 resulting in a decline in poverty from 55.3 percent to 33.5 percent, (UN-OHRLLS, 2016). These are indications that poverty is 
very high in Ethiopia. The paradox of this is that the country is endowed with abundant natural resources which create favorable condition for rapid economic growth. According to (Godswill, Dawit, \& Dejene, 2007) Ethiopia has an estimated 55 million ha of arable land out of which only $40 \%$ is cultivated. The country also is endowed with eight major river basins which can irrigate about 3.5 million ha of land. However, only $5 \%$ of this potentially irrigable land is irrigated. The estimate ranges between 150,000 and 160,000 ha. Thus, we can say that the country has not made use of the existing resources, let alone improving it with new technologies, so as to come out of the chronic poverty. The United Nations Development Program in 2013 ranked the Human Development Index of the country as 173rd out of 187 countries. According to the World Economic Forum 2013-14 Global Competitiveness Report Ethiopia is ranked 127th out of 148 countries (Wikipedia, 2016).

According to (John W. \& Paul, 2010), if a country could maintain a growth rate in agricultural GDP of six percent, it could provide enough employment growth to contribute to the rapid economic transformation of the economy and rapid decline in poverty. But, according to (World Bank, 2016) out of the overall average yearly growth rate of 10.9 percent between 2004 to 2015 , agriculture grew by only 3.6 percent while service grew by 5.4 percent and industry grew by 1.7 percent. The country is following an economic growth and development strategy known as ADLI (agricultural development led industrialization) (Government of Ethiopia, 2016). This strategy is supported by an economic reform program developed in cooperation with the World Bank and the International Monetary Fund (IMF) and on a series of structural adjustment programs since 1992. The long term objective of this strategy was achieving industrialization through the development of the agricultural sector (Government of Ethiopia, 2016). But, this long term objective has not been achieved even after a quarter of a century after its inception.

Thus, this paper tries to address the macroeconomic determinants of economic growth of Ethiopia.

\subsection{Objective}

The objective of this paper is to investigate the macroeconomic determinants of economic growth in Ethiopia. This will be an input for the policy makers and others concerned towards to facilitate growth and developments of the country.

\section{REVIEW OF RELATED LITERATURES}

According to Aigbokhan (1995), Economic growth means an increase in the average rate of output produce per person usually measured on a per annum basic. It is also the rate of change in national output or income in a given period. Economic growth is the increase of per capital gross domestic product (GDP) or other measure of aggregate income. It is often measured as the rate of change in real GDP. Economic growth refers only to the quantity of goods and services produced. Godwin (2007) defines economic growth as an increase in real gross domestic product (GDP). That is, gross domestic product adjusted for inflation. The growth can either be positive or negative. Negative growth can be referred to by saying that the economy is shrinking. This is characterized with economic recession and economic depression.

Ullah and Rauf (2013) asserted that a sound macroeconomic policy has to do largely with the consistent management of short-term policy instruments pursuing a sustainable and predictable pace for aggregate economic variables and major prices (wages, inflation, interest rates and exchange rates). They established further that monetary, fiscal and exchange rate policies, together with structural reform, have major consequences for the social wellbeing of societies, not only in terms of protection against shocks and crises but also in terms of equity. Many, if not all, of the necessary social policies are of a domestic nature. Pursuing them, however, depends to a considerable extent on the international enabling environment in which the global financial system, the unsettled debt crisis and increasing official development assistance (ODA) flows play a significant role.

The Neo classical growth models of Solow (1956) and Swan (1956) believed that, in the long run that technological progress and population growth are the main determinant of economic growth. They are of the view that government can influence the population growth rate, saving rate and incentive to invest in human and physical investment through its different policies such as fiscal, monetary, income and exchange rate policies. These policies can change the equilibrium factor ratio or affect the transition path of steady state growth rate. While endogenous growth model by Barro (1990), Lucas (1990) and King and Rebelo (1990) believed that physical and human capital do affect economic growth but fiscal policy variables like distortionary taxation and productive expenditure affect the output level and its steady growth rate. According to Neo classical growth model, impact of fiscal policy on steady economic growth is temporary and not the permanent one.

Over the last few decades the macroeconomic policies and economic growth relationship became the hot issue amongst the government, policy makers and researchers. There is a growing literature on the determinants of economic growth in cross countries and country specific with varied submission and conclusion. For examples Barro (1995) examined the determinants of economic growth and the empirical findings for a panel of around 100 countries from 1960 to 1990 strongly support the general notion of conditional convergence. For a 
given starting level of real per capita GDP, the growth rate is enhanced by higher initial schooling and life expectancy, lower fertility, lower government consumption, better maintenance of the rule of law, lower inflation, and improvements in the terms of trade while growth is negatively related to the initial level of real per capita GDP. Political freedom has only a weak effect on growth but there is some indication of a nonlinear relation and concluded that there is a strong positive influence of the standard of living on a country's propensity to experience democracy.

Antwi, Mills and Zhao (2013) study the impact of macroeconomic factors on economic growth in Ghana for the period 1980 to 2010 by means of Cointegration and error correction models using yearly data for the period and then recommend actions that should be taken to speed up the growth process in the country. The findings showed that long-run economic growth is largely explained by physical capital, foreign direct investment, foreign aid, inflation and government expenditure. It is also evident that economic growth is not affected by shortterms changes in labor force. The estimated coefficient of the ECM indicates a mild speed of adjustment to equilibrium. They recommended that government must reform the tax system and improve its budget balance and government should continue to direct foreign assistance into the programmes that produce public capital since this improves the productivity of the masses and hence, is likely to have a positive long run effect on economic growth. Ullah and Rauf (2013) evaluate the impacts of macroeconomic variables on economic growth in case of some selected Asian countries using panel data from 1990 to 2010 and found that the sample countries economic growth is positively affected by foreign direct investment and saving rate while exports have negative impacts on economic growth and labor force and tax rate have no impacts on economic growth.

Aurangzeb and Ul Haq (2012) asserted that Investment plays an important role in driving growth through increase in productivity levels. Foreign direct investment brings technology and creates employment. It helps to adopt new methods of production and enhances productivity by bringing competition in the economy. Foreign direct investment also introduces to novice management and organizational skills, and explores hidden markets in the economy. It reduces the barriers in adoption of technology and brings improvements in the quality of labor and capital inputs in the host economy. Furthermore investigating the impact of investment on the economic growth using multiple regression technique and found that public investment, private investment and foreign direct investment contribute to economic growth significantly concluded that bi directional relationship of gross domestic production with foreign direct investment and public investment while unidirectional relationship of gross domestic production is found with private investment and recommended that Pakistan should make stronger efforts to attract as much FDI as possible to the foreign exchange sectors in the short term.

Rahman and Salahuddin (2010) empirically analyzed the relationship between economic growth and its determinants, with special focus on stock market development. Using data for the period from 1971 to 2006 and employed FMOLS and ARDL bounds testing for the long run relationship and ECM for the short run dynamics, the findings suggest a positive relationship between efficient stock markets and economic growth, both in short run and long run while financial instability and inflation have negative effects. Furthermore human capital, foreign direct investment and stock market liquidity have positive effects on economic growth.

Zafar and Zahid (2013) examine the effects of some of the key macroeconomic variables on economic growth. Employing multiple regression framework and time series data over the period from 1959-60 to 1996-97. The quantitative evidence shows that primary education to be an important precondition for accelerating growth. Similarly, increasing the stock of physical capital and openness of the economy contribute to growth. The empirical results also suggested that budget deficit and external debt is negatively related to economic growth, suggesting that relying on domestic resources is the best alternative to finance growth and reinforce the importance of sensible long-run growth-oriented policies to obtain sustainable growth.

\section{METHODOLOGY}

The study of this paper is based on secondary data which are believed to help in achieving the objective of the study. For this purpose, we collected secondary data from the National Bank of Ethiopia (NBE), Central Statistical agency (CSA), Ministry of Finance and Economic Development (MoFED), Ethiopia economic association (EEA), Ethiopia investment commission (EIC) and world development indicator(WDI) are most of the sources that we relied on for the analysis. The paper is model analysis based on time series annual data ranging from 1991 up to 2017. Specifically the ARDL and ECM, the error correction model is used for investigate the short run as well as long run relationship between economic growth and its determinants. The regressions and the various tests were conducted by using Eviews 10 software.

\subsection{Theoretical Framework and Model Specification}

Macroeconomic theory has identified various factors that influence the growth of a country from the classical, neoclassical and the new growth theories. Antwi, Mill and Zhao (2013) asserted that these factors include natural resources, investment, human capital, innovation, technology, economic policies, governmental factors, foreign aid, trade openness, institutional framework, foreign direct investment, political factors, socio-cultural factors, 
geography, demography and many others. In order to examine the empirical evidence of the macroeconomic factors of economic growth in Ethiopia, the study considers most of these factors. Following broadly the approach adopted in Lucas (1988), the researcher specifies the economic growth function for Ethiopia as follows: Real gross domestic product is a function of physical capital, labor force, and foreign direct investment, openness of the economy, inflation, government expenditure and export. It is precisely expressed as follows:

$\mathrm{RGDP}=\mathrm{f}(\mathrm{K}, \mathrm{L}, \mathrm{FDI}, \mathrm{OPEN}, \mathrm{INF}, \mathrm{GE}, \mathrm{EX})$

Thus, our growth function becomes:

$\mathrm{RGDP}=\beta 0+\beta 1 \mathrm{~K}+\beta 2 \mathrm{~L}+\beta 3 \mathrm{FDI}+\beta 4 \mathrm{OPEN}+\beta 5 \mathrm{INF}+\beta 6 \mathrm{GE}+\beta 7 \mathrm{EX}+\mathrm{Ut}$

Where, RGDP represents the real gross domestic product $\mathbf{K}$ Represents Physical Capital measured as Gross Fixed Capital Formation L Represents Total Labor Force FDI Represents Foreign Direct Investment OPEN Represents openness of the economy measured as export + import/gross domestic product INF Represents Inflationary Rate GE Represents total Government Expenditure, EX represent volume of export and Ut is the error term assumed to be normally and independently distributed with zero mean and constant variance, which captures all other explanatory variables which influence economic growth but are not captured in the model. B1, $\beta 2, \beta 3,4 \beta 4, \beta 5, \beta 6$, and $\beta 7$ are the partial elasticity of real GDP.

\subsection{Estimation Strategy}

Regarding the estimation strategy, the researcher follows three steps:

i) the test of stationary of the individual series in the regression model or otherwise to determine the order of integration of the variables,

ii) the test of the existence of a stable long-run equilibrium relationship among the variables in the model and

iii) iii) The estimation of the parameters of the model in equation 2

\subsubsection{Unit Root Testing (Stationary Test)}

In estimating parameters of a time series model, it is required that all data should be tested in order to determine the order of integration of each of the variables specified in the model. Testing for stationarity before estimation is deemed necessary as most time series variables are nonstationary and estimations with these series might produce spurious results. Testing for stationarity enables the researcher to determine the order of integration of the variables so as to choose an appropriate estimator. The study chooses for the use of the Augmented Dickey Fuller (ADF) tests in carrying out the stationarity test. These tests are employed concurrently for robust results. The lag length is selected using Schwarz Information Criterion (SIC).

\subsubsection{Augmented Dickey Fuller (ADF) Test}

The ADF test developed by Dickey and Fuller (1979) is an augmented version of the Dickey-Fuller (DF) test for more complicated and larger time series models. The augmentation term is included in order to change the residuals into white noise without changing the distribution of the test statistics under the null hypothesis of a unit root. The procedure of stationarity testing using the ADF is similar to that of the DF test but rather applied to a particular model as specified below.

$\Delta \mathrm{Y}_{\mathrm{t}}=\alpha+\delta_{\mathrm{t}}+\lambda \mathrm{Y}_{\mathrm{t}-1}+\mathrm{B}_{1} \Delta \mathrm{Y}_{\mathrm{t}-1}+\ldots+\mathrm{B}_{\mathrm{j}-\mathrm{i}} \Delta \mathrm{Y}_{\mathrm{t}-\mathrm{j}+1}+\mu_{\mathrm{t}}$

Simply,

$\Delta \mathrm{Y}_{\mathrm{t}}=\alpha+\delta_{\mathrm{t}}+\lambda \mathrm{Y}_{\mathrm{t}-1}+\sum_{\mathrm{t}=1}^{\mathrm{j}} \mathrm{B}_{1} \Delta \mathrm{Y}_{\mathrm{t}-1}+\mu_{\mathrm{t}}$

Where $\alpha$ is a constant term, $\delta$ is the coefficient of the time trend, $\mathrm{j}$ is the optimal lag length, $\Delta$ is the difference operator, $\mathrm{t}$ represents the time trend and $\mu$ represents the Gaussian white noise. The test for stationarity is carried out under the null hypothesis $\lambda=0$ as against the alternative hypothesis $\lambda<0$. After computation of the test statistic, it is then compared with the critical values. Therefore, if the test statistics is larger than the critical value, then the null hypothesis of $\lambda=0$ is rejected implying that there is an absence of unit root (stationarity). Similarly, the acceptance of the null hypothesis implies that the series has a unit root and hence non stationary. In this case the test statistics is lesser than the critical values.

\subsubsection{Cointegration Testing}

Variables in time series analysis are classified as co-integrated if they exhibit long-run equilibrium relationship and share common trends. For the purposes of this study the Bound test within the Auto-Regressive Distributed Lag (ARDL) as proposed by Pesaran et al (2001) is employed. The reasons for using this approach rather than the conventional approaches such as the Johansen (1998) and Johansen and Juselius (1990) are based on several considerations. The ARDL model gives consistent results irrespective of the order of integration of the variables under study. Thus whether I(1) or I(0) or a mixture of both but not orders greater than one. It also gives an unbiased estimation of the long-run model and also provides reliable t-statistics though some of the regressors might be endogenous. The ARDL estimation technique is also very efficient in the cases of small samples as in the case of this study. This technique also allows for the introduction of optimal lags of both the dependent and explanatory variables. Implying that, various variables are allowed to have their optimal speed of adjustment to the equilibrium. A generalized representation of the ARDL model is shown in 3.15. 


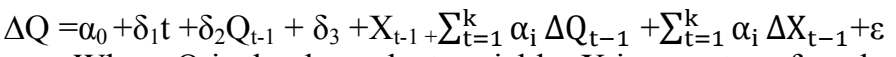

Where $\mathrm{Q}$ is the dependent variable; $\mathrm{X}$ is a vector of explanatory variables; $t$ represents the time trend and $\varepsilon$ represents the error term.

The F-test statistic is used in checking the existence of a long-run equilibrium among the variables under study. The null hypothesis for no cointegration among the variables is represented as $\mathrm{H}_{0:} \delta_{1}=\delta_{2}=\delta_{3}=0$ while the alternative hypothesis is represented by $\mathrm{H}_{1}: \delta_{1} \neq \delta_{2} \neq \delta 3 \neq 0$. The F-statistic test is a non-standard which relies on whether the variables included in the model are integrated of order zero I(0) or integrated of order one I(1), the number of regressors and whether the model contains a trend and/or an intercept. The test involves the use of critical value bounds which depends on the order of integration of the variables. Thus whether $\mathrm{I}(0)$ or $\mathrm{I}(1)$ or a mixture of both. Basically two sets of critical values (i.e. I(0) series and I(1) series) are generated. The lower bound critical values is the term used to classify the critical values generated for the $\mathrm{I}(0)$ series, whilst the critical values for the I(1) series is referred to as the upper bound critical values.

After generation of the F-statistic estimates, if the F-statistic greater than the upper critical value, then the null hypothesis is rejected and conclusion is made that, there is an existence of a long-run equilibrium relationship between variables irrespective of the order of integration. On the other hand, if the F-statistic is less than the lower bound critical value then the null hypothesis is accepted implying that there is no cointegration between variables. However, if the test statistic lies in-between the upper critical value and lower critical value a conclusive inference cannot be made.

\subsubsection{Error Correction Model}

After the test of cointegration, the long-run relationship between variables is established by using the ARDL test for cointegration. The error-correction model (ECM) within the ARDL framework is estimated in order to obtain the short run and long run relationships among the economic variables understudy. The lag length selection criterion is based on the Schwarz information criteria (SIC). A generalized form of the ECM within the ARDL frame work is represented below:

$\Delta \mathrm{Q}_{\mathrm{t}}=\beta_{0}+y_{1} \mathrm{Q}_{\mathrm{t}-1}+\mathrm{y}_{2} \mathrm{X}_{\mathrm{t}-1}+\sum_{\mathrm{t}=1}^{\mathrm{p}} \delta_{1} \Delta \mathrm{Q}_{\mathrm{t}-1}+\sum_{\mathrm{t}=0}^{\mathrm{q}} \delta_{2} \Delta \mathrm{X}_{\mathrm{t}-1}+\Psi \mathrm{ECT}_{\mathrm{t}-1}+\mu \ldots$ (3.6)

Where $Q$ represents the dependent variable, $X$ represents the regressors, $y_{1}$ and $y_{2}$ represents the long run coefficient estimators, $\delta_{1}$ and $\delta_{2}$ represents the short run dynamic coefficients, $\Psi$ represents the speed of adjustment parameter, ECT represents the error correction term.

\section{EMPIRICAL RESULTS AND INTERPRETATION}

\subsection{Unit Root Test}

The unit root test in Table4.1 shows that real gross domestic product, Gross Fixed Capital Formation, openness of the economy, total government expenditure and export are stationary at first difference 1(1), since the ADF F-statistic value of each of the variables at first difference is greater than the McKinnon $5 \%$ critical values, while total Labor Force, inflationary rate and foreign direct investment are stationary at level because the ADF F-statistic value of each variable at level is greater than the McKinnon 5\% critical values.

Table4.1 unit root test

\begin{tabular}{|c|c|c|c|c|}
\hline \multirow[t]{2}{*}{ variables } & \multicolumn{2}{|c|}{ Stationary at level } & \multicolumn{2}{|c|}{ Stationary at first difference } \\
\hline & Constant & Constant and trend & Constant & Constant and trend \\
\hline $\operatorname{lnRGDP}$ & 2.853 & 0.080 & $-4.675 * * *$ & $-5.745 * * *$ \\
\hline $\ln K$ & 2.619 & 1.098 & $-6.376 * * *$ & $-6.628 * * *$ \\
\hline $\ln \mathrm{L}$ & $-3.106 * *$ & $-3.695 * *$ & & \\
\hline open & -3.258 & -0.493 & $-3.443 * *$ & $-4.615 * *$ \\
\hline inf & $-5.134 * * *$ & $-5.577 * *$ & & \\
\hline $\operatorname{lnGC}$ & 1.020 & 1.585 & $-5.412 * * *$ & $5.437 * * *$ \\
\hline $\operatorname{lnFDI}$ & $-4.022 * * *$ & $-4.358 * * *$ & & \\
\hline $\operatorname{lnEX}$ & -2.633 & -3.129 & $-6.267 * * *$ & $-6.753 * * *$ \\
\hline
\end{tabular}

Note: $* * *$ and $* *$ denotes significance at $1 \%$ and $5 \%$ respectively

Source: Author's own construction 
The results obtained in Augmented Dickey Fuller tests (ADF tests) show mix results in terms of the order of integration of the variables. In other words the underlying series of the variables in the study are integrated of order zero I(0) and order one I(1) hence offering support for the use of ARDL bounds test to cointegration. This implies that all the variables were found to be mean reverting.

\subsection{Cointegration Test Results}

In order to determine the possible presence of cointegration thus a long-run equilibrium among the variables included in equation 3.2 the study adopts the bounds testing approach within the ARDL framework to test for cointegration. The results are presented in Table 4.2.

The ARDL model $(1,0,1,0,0,0,1,0)$ selection was based on the Schwarz information criterion (SIC). The result in Table 4.2 shows that there exists a stable long-run relationship among the variables included in equation 3.2. The computed F-statistics of the bound test 15.69 is larger than the upper bound critical value of 3.45 at $1 \%$ level of significance. In this case the null hypothesis of no cointegration is rejected implying that there is a stable long-run equilibrium relationship among the variables (cointegration) in equation 3.2. This implies that there is a long-run relationship among the variables included in estimated model.

Table4. 1: Results of Cointegration relationship (Bound test)

\begin{tabular}{|l|l|l|}
\hline \multicolumn{2}{|c|}{ Critical Values } \\
\hline Computed F-statistic & $99 \%$ Lower Bound & $99 \%$ Upper Bound \\
\hline $15.69 * * *$ & 2.277 & 3.5 \\
\hline
\end{tabular}

Note: $* * *$ means that the null hypothesis of no long-run equilibrium (no cointegration)

is rejected at $1 \%$ level of significance.

Source: Author's own construction

\subsection{Long-run Relationship between Macro Variable Determinants and Economic Growth in Ethiopia}

We have established in the previous sections that there is a long-run (cointegration) relationship among macro variables in order to achieve the objectives of the study. The results are presented in Table4.3.

The regression result shown in Table 4.3, shows a significant Positive relationship between gross fixed capital formation and economic growth. One percent increase in gross fixed capital formation, ceteris paribus, will lead to about 0.68 percent increase in Ethiopian economic growth. This result supports the fact that increasing investment size enhances productivity which has a spillover effect on economic performance.

Total labor force has a significant positive relationship with economic growth suggesting that its contribution to economic output is very high as results of having productive workers. One percent increase in total labor force, ceteris paribus, will lead to about 0.69 percent increase in Ethiopian economic growth.

Table4. 2 Estimated Long-run

ARDL $(1,0,1,0,0,0,1,0)$ selected based on SIC Dependent Variable: InRGDP

\begin{tabular}{|c|r|r|r|c|}
\hline Variable & Coefficient & Std. Error & t-Statistic & Prob. \\
\hline LNK & 0.684685 & 0.114292 & 5.990661 & 0.0000 \\
\hline LNL & 0.689658 & 0.314730 & 2.191270 & 0.0446 \\
\hline OPEN & -0.316430 & 0.383857 & -0.824342 & 0.4227 \\
\hline INF & -0.000657 & 0.001170 & -0.561542 & 0.5827 \\
\hline LNGC & 0.161901 & 0.070355 & 2.301223 & 0.0361 \\
\hline LNFDI & -0.046001 & 0.018511 & -2.485019 & 0.0252 \\
\hline LNEX & -0.090488 & 0.052966 & -1.708414 & 0.1082 \\
\hline C & -7.064790 & 4.391496 & -1.608743 & 0.1285 \\
\hline
\end{tabular}

Source: Author's own construction

The result shows that the coefficient of openness of the economy is negative but insignificant such that one percent increase in openness of the economy will leads to 32 percent decrease in Ethiopian economic growth. This suggests that the liberalization of the Ethiopian economy to international economy has negative impact on the nation economic performance. The implication of this result is that the Ethiopian external trade which is dominated by inelastic demand and imports are elastic demand, which is not affected by price movement as inelastic demand.

The result further revealed that inflation rate is negative but insignificant such that one percent increase in inflationary rate will leads to 0.067 percent decreases in Ethiopian economic growth. The implication of this result is that INF is a not major macroeconomic determinant of economic growth in Ethiopia.

The result also shows that the coefficient of total government expenditure has a significant positive effect on Ethiopian economic growth such that one percent increase in government expenditure will leads to 0.16 percent increase in Ethiopian economic performance. This is consistent with standard theories and economic expectation because the higher government expenditure on productive venture the greater economic output, 
ceteris paribus.

Foreign direct investment has a negative correlation with Ethiopian economic growth. This is in line with expectation as more inflow of FDI has a crowd out effects on domestic savings and investment which is one of the most feared conditions for developing country economic growth i.e Ethiopia. From the result, the coefficient of FDI is significantly negative (at 5 percent significant level). The implication of this result is that FDI is a major macroeconomic determinant of economic growth in Ethiopia.

The result shows that the coefficient of export is negative but insignificant such that one percent increase in export of the economy will leads to 0.09 percent decrease in Ethiopian economic growth. This suggests that the country export has no impact on the nation economic performance. The implication of this result is that the Ethiopian external trade which is dominated by export of primary product is price inelastic and has not increase growth in the country due to its greatly influenced by instability in the world market price.

\subsection{Short-run Relationship between Macroeconomic determinants and Economic Growth in Ethiopia}

The previous section has analyzed the long-run (cointegration) relationship among the variables included in equation 3.2. In this section, and in order to achieve the objective of the study, focuses on the short-run relationship among variables included in equation 3.2. To achieve this equation the error correction model of equation 3.6 was estimated. The results are presented in Table 4.4.

The total labor force and foreign direct investment have significant effects on real GDP with negative signs. That means, a change in these variables will have negative impact on the real GDP of Ethiopian economy in the short run

Table 4.4 Estimated Short -run

ARDL $(1,0,1,0,0,0,1,0)$ selected based on SIC Dependent Variable: InRGDP

\begin{tabular}{|c|c|c|c|c|}
\hline \multicolumn{5}{|c|}{$\begin{array}{c}\text { ECM Regression } \\
\text { Case 2: Restricted Constant and No Trend }\end{array}$} \\
\hline Variable & Coefficient & Std. Error & t-Statistic & Prob. \\
\hline $\mathrm{D}(\mathrm{LNL})$ & -8.951572 & 0.854647 & -10.47400 & 0.0000 \\
\hline D(LNFDI) & -0.017954 & 0.008167 & -2.198398 & 0.0440 \\
\hline CointEq(-1)* & -0.951775 & 0.064676 & -14.71606 & 0.0000 \\
\hline R-squared & 0.905923 & Mean dependent var & 0.097371 & \\
\hline Adjusted R-squared & 0.897742 & S.D. dependent var & 0.134568 & \\
\hline S.E. of regression & 0.043032 & Akaike info criterion & -3.345582 & \\
\hline Sum squared resid & 0.042590 & Schwarz criterion & -3.200417 & \\
\hline Log likelihood & 46.49256 & Hannan-Quinn criter. & -3.303780 & \\
\hline Durbin-Watson stat & 2.389406 & & & \\
\hline
\end{tabular}

Source: Author's own construction

Finally from economic intuition, the error correction term (ECT-1) in the ECM measures is the speed at which an endogenous variable adjusts to shocks in an explanatory variable in order to converge to its long run equilibrium. The estimated ECT-1 coefficient must be negative and statistically significant at one percent error level. The negative and significant coefficient of the ECT-1 confirms the cointegration results discussed in section 3.6. The ECT-1 explains the extent to which the explanatory variable returns to the equilibrium in the long-run after a short-run shock. The result shows a high speed of adjustment of convergence to the long run equilibrium every year after a short run shock. In other words, the coefficient -0.95 indicates high rate of convergence to equilibrium, which implies that the deviation from long-term equilibrium is corrected by 95 percent over each year.

The coefficient of determinations $\mathrm{R}^{2}$ of 0.91 indicates that about 91 percent of the total variations in Ethiopian economic growth are explained by the variations in its macroeconomic variables. This shows that our model explains large proportion of variations in economic growth in Ethiopian and also represents a good measure of fit. The F-statistic shows overall significance of the model. The F-statistic is significant at $1 \%$ level. The probability of its value $(0.000)$ is less than the 0.01 critical levels.

In order to test the statistical adequacy of the model the study conducts diagnostic and stability tests. The results presented in Table 4.5 shows that there is no evidence of serial correlation or heteroskedasticity in the model. The LM version serial correlation test result gives a co-efficient of 1.61 and a probability value of 0.205 hence the null hypothesis of non-existence of serial correlation is not rejected against the alternative hypothesis of existence of serial correlation. Again, the LM version hetroskedasticity test gives a coefficient value of 10.90 and a probability value of 0.365 , hence the non-rejection of the null hypothesis of no hetroskedasticity. The 
probability values of the functional form and normality tests are 0.794 and 0.67 respectively, hence statistically significant. This therefore implies that the model does not exhibit any functional or normality problems.

Table 4.5 Results of Diagnostics and Stability test

\begin{tabular}{|l|l|}
\hline TEST STATISTICS & RESULTS \\
\hline SERIAL CORRELATION & 1.610 \\
& $(0.205)$ \\
\hline NORMALITY & 0.794 \\
& $(0.670)$ \\
\hline HETEROSKEDASTICITY & 10.90 \\
& $(0.365)$ \\
\hline CUSUM & STABLE \\
\hline
\end{tabular}

Source: Author's own construction

Note: In parentheses are probability values

In addition, in order to determine if the estimated regression equations are stable throughout the sample period, plots of the CUSUM tests as proposed by Brown et al (1975) and suggested by Pesaran et al (2001) within the ARDL framework are performed. The CUSUM residuals line within the $5 \%$ critical value bounds (see figure 4.1) implying stability in the model. Hence it can be concluded that the regression equation is stable throughout the sample period considered.

\section{Figure 4.1 Stability test of the model}

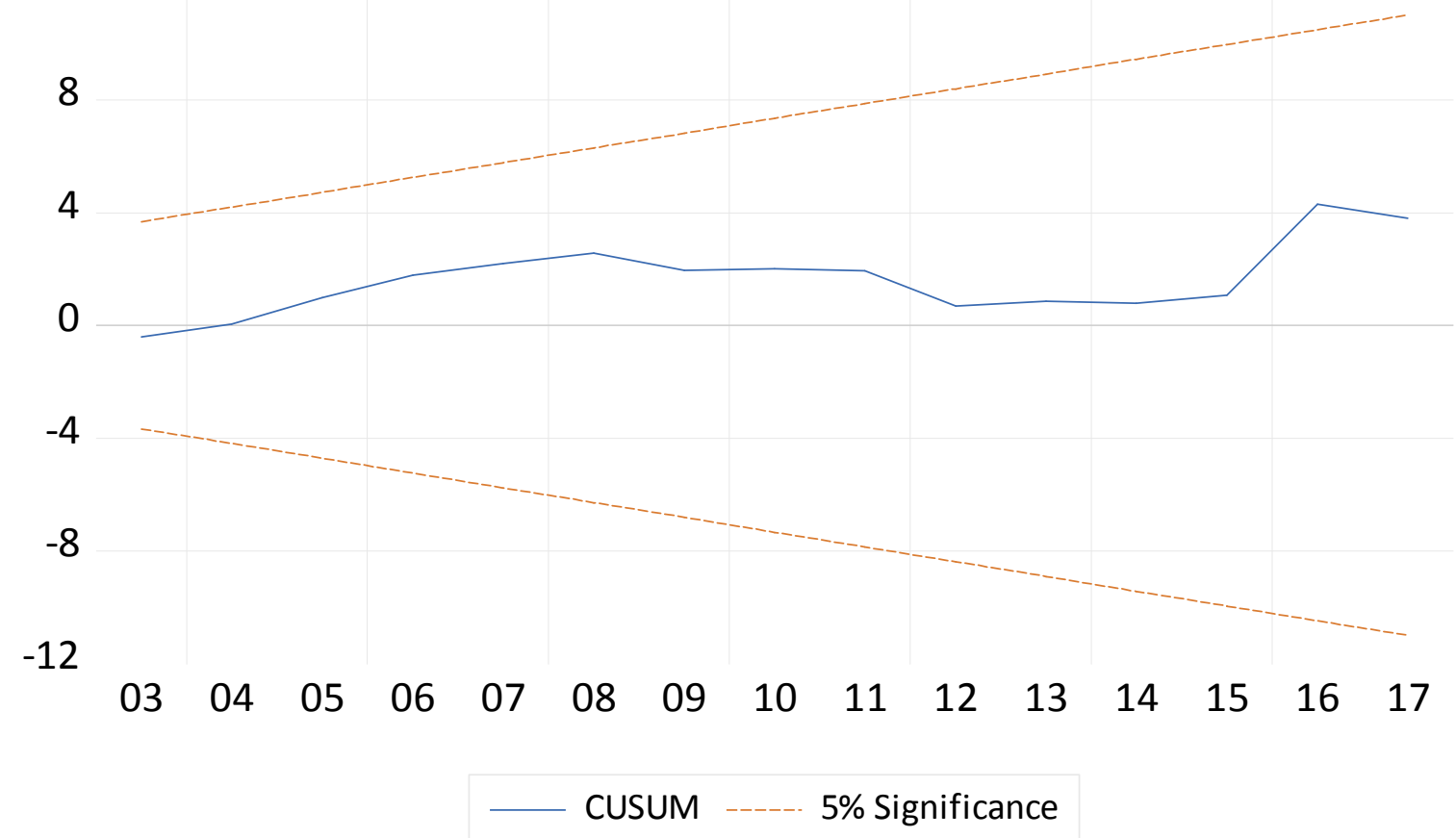

Source: Author's own construction

\section{CONCLUSION AND RECOMMENDATION}

\subsection{Conclusion}

The study is investigated on the macroeconomic determinants of the Ethiopian economic growth. The study used autoregressive distributed lag model under bound test on the annual time series data ranging from 1991-2017. The variables were tested for stationary and co-integration analysis was also carried out via the Augmented Dickey Fuller (ADF) method. Also error correction test was performed. The study found that the economic growth and selected macroeconomic variables included has a long run relationship with economics output performance. The study also reveals that gross fixed capital formation, total labor force, total government expenditure and foreign direct investment are the macroeconomic variables that determined Ethiopian economic growth but openness to international economy, inflation and volume of export has an insignificant effect on determined Ethiopian economic growth. These variables i.e. Gross fixed capital formation, total labor force and total government expenditure will have positive impact on the real GDP of Ethiopian in the long run. The foreign direct investment also has expected negative sign. Contrary to our expectation, the openness of the economy, inflation and export has negative impacts on the real GDP of the Ethiopian economy in the long run but 
insignificant. That means that a change in these variables will does not affect the real GDP of the country. Unfortunately, none of the above impacts are statistically significant at $5 \%$ level of significance. That is to say, statistically all the variables considered in the model does not affect the real gross domestic gross domestic product of Ethiopia in the long run. The short run error correction model shows that the total labor force and foreign direct investment has negative and significantly effects on Ethiopian economic growth in the short run.

\subsection{Recommendation}

The study shows that gross fixed capital formation, total labor force and total government expenditure are the macroeconomic variables that boost Ethiopian economic growth, since they have positive relationship with economic growth. Accordingly government should encourage saving and investment by designing and implementing policies that encourages the citizens to save and creating conducive environment for investment. In relation to the total labor force it has positive effects on Ethiopian economic growth, then the government can be encourage or create incentives for workers by siting minimum wage, creating favorable condition for worker by expanding investment. The study also indicated that government spending has positive and significant impact Ethiopian economic growth. This is the nature of poor countries where people rely heavily on these transfers from governments. The Ethiopian government should continue with its social welfare expenditures as this has positive and significant impact on the economic growth of the country.

The coefficient of openness of the economy shows that there is a negative relationship with Ethiopian economic growth. This suggests that the development of the Ethiopian international trade system has negative impact on the nation economic performance. The implication of this result is that the country must be follow a mixed economy rather than free liberalized economy.

Considering the fact that the export sector is mainly dominated by agricultural products, policies to improve upon the agricultural sector can be enforced. Policy makers can invest in newly improved agro-technologies and agro-machines to aid farmers increase production, hence output volumes. Again, various technologies on how to process major agricultural products into finished goods before exports can be considered as this will help to diversify the country's export goods. Policies that enhance the diversification and facilitate shift towards the export of semi processed and manufactured goods are essential.

\section{Reference}

Aigbokhan, B. (1995). Macroeconomic: Theory Policy and Evidence. Benin City Idenijies publisher.

Antwi, S., Mills, E.F and Zhao, X . (2013). Impact of Macroeconomic Factors on Economic Growth in Ghana: A Cointegration Analysis. International Journal of Academic Research inAccounting, Finance and Management Sciences, 3 (1) , 35-45.

Aurangzeb, D and Ul Haq, A. (2012). Impact of Investment Activities on Economic Growth of Pakistan. Business and Management Review, 2(1), 92 - 100.

Brada, J. C. Kutan, A. M. and Zhou, S. (1997). The Exchange Rate and The Balance Of Trade: The Turkish Experience. The Journal of Development Studies, 33(5), 675-692.

Dickey, D. A. and W. A. Fuller . (1979). Distribution of the Estimators for Autoregressive Time Series with a Unit Root. Journal of the American Statistical Association, 74(366a), 427-431.

Godswill, M., Dawit, K., \& Dejene, A. (). . (2007). A Comaparative analysis of rainfed andirrigated agricultural production in Ethiopia. Springer Science and Business Media B.V.

Johansen, S. (1988). Statistical Analysis of Cointegration Vectors. Journal of economic dynamics and control, 12(2), 231-254

Johansen, S. and Juselius, K. . (1990). Maximum likelihood estimation and inference on cointegration with applications to the demand for money. Oxford Bulletin of Economics and statistics, 52(2), 169-210.

John W. M. \& Paul, D. (2010). Agriculture and the economic Ttransformation of Ethiopia: Ethiopian Strategy Support Program 2. ESSP2 Working Paper No. ESSP2010.

Lucas, R. (1988). On the Mechanics of Economic Development. Journal of Monetary Economics, 22 (1), 3-42.

Pesaran M. H. Shin, Y. and Smith R. J. (2001). Bounds Testing Approaches to the Analysis of Level Relationships. Journal of Applied Econometrics, 16(February 1999), 289-326.

Rahman, M.M and Salahuddin, M. (2010). The Determinants of Economic Growth in Pakistan: Does stock Market Development Play a Major Role? Economic Issues, 15(2), 69- 86.

Solow, R. (1956). A Contribution to Theory of Economic Growth. Quarterly Journal of Economics, 71.

Swan, T. W. (1956). Economic Growth and Capital Accumulation. Economic Record 32.

Todaro, M.P. and Smith. S.C. (2009). Economic Development. Tenthedition.

Ullah, Fand Rauf, A. (2013). Impacts of Macroeconomic Variables on Economic Growth: A Panel Data Analysis of Selected Asian Countries. GE-International Journal of Engineering Research.

UN-OHRLLS. (2016). State of the Least Developed Countries: Follow Up of the implementation of the Istanbul Program of Action for the Least Developed Countries. https://issuu.com/unohrlls. 
Wikipedia. (2016, December 26). Ethiopia. Retrieved December 31, 2016, from. Wikipedia: https://en.wikipedia.org/wiki/Ethiopia .

WorldBank. (2016). ETHIOPIA'S GREAT RUN: THE GROWTH ACCELERATION AND HOW TO PACE IT. Washington DC: World Bank Group.

Zafar, I. and Zahid, G. (2013). Macroeconomic Determinants of Economic Growth in Pakistan. The Pakistan Development Review, 37 (2), 125-148. 